\title{
THE INFLUENCES OF MIGRANT SETTLEMENT TO THE LOCAL COMMUNITY: AN ANALYSIS OF SOCIO-ECONOMIC ASPECT (Case of Ampenan and Sekarbela, Mataram Municipality)
}

\author{
Reba Anindyajati Pratama'
}

Diterima : 18 Juni 2015

Disetujui : 31 Desember 2015

\begin{abstract}
Many cities in Indonesia are experiencing the high level of migration as the symptom urbanization process. In the other hand, the presence of the migrant in the urban area will bring changes to the local environment. As the case, Central Statistical Bureau reported Mataram has experienced $31 \%$ of recent migration in the province or recorded 36.326 new migrant during 2007-2012. Furthermore, Ampenan as one of the main sub district has been split into Sekarbela to accommodate the pressure of urban demand. This research aims to eradicate the existence of migrant and its influences in Ampenan and Sekarbela from socio-economic aspects. Specific objectives of the research are; eradicating the interaction between migrant and the place, and analyzing the influences of migrant settlement to the local community. This research finds there are different patterns on how lower and upper-middle migrant resided and contributed to the area of Ampenan and Sekarbela. The lower-middle migrant tend to have more influence to the informal sector and social relationship in the old town of Ampenan. The upper-middle migrant tend to have more influence in socio-economic transformation of the local people in Sekarbela due to the need of the new development.
\end{abstract}

Keywords: Migration, Migrant Settlement, Upper-middle, Lower-middle

\begin{abstract}
ABSTRAK
Kota-kota di Indonesia sedang mengalami fenomena tingginya migrasi sebagai perwujudan dari proses urbanisasi. Di sisi lain, kehadiran migran di perkotaan akan membawa perubahan pada lingkungan setempat. Sebagai contoh, Kota Mataram memiliki 31\% angka migrasi 5 tahunan dari total migrasi di provinsi atau setara 36,326 migran selama 2007-2012. Selanjutnya, Ampenan sebagai salah satu kecamatan utama mengalami pemekaran menjadi Sekarbela untuk mengakomodasi tekanan pertumbuhan kota. Penelitian ini bertujuan untuk mengungkap keberadaan migran dan pengaruhnya di Ampenan dan Sekarbela dari aspek sosio-ekonomi. Tujuan khusus dari penelitian ini adalah; mengidentifikasi hubungan/ interaksi antara migran dan lokasi tujuan, dan menganalisis pengaruh dari pemukiman migran terhadap masyarakat sekitar. Penelitian ini menemukan perbedaan pola konsentrasi dan kontribusi sosio-ekonomi antara migran menengah-bawah dan menengah-atas di Ampenan dan Sekarbela. Migran menengah-bawah cenderung memiliki pengaruh yang lebih besar pada sektor informal dan hubungan sosial di wilayah kota tua Ampenan. Migran menengah-atas cenderung memiliki pengaruh yang lebih besar dalam hal mendorong transformasi sosial-ekonomi masyarakat lokal di Sekarbela sebagai akibat adanya kebutuhan pembangunan yang baru.
\end{abstract}

Kata Kunci: Migrasi, Permukiman Migran, Menengah-atas, Menengah-bawah

\footnotetext{
${ }^{1}$ Mahasiswa Magister Pembangunan Wilayah dan Kota, Fakultas Teknik, Universitas Diponegoro

Kontak penulis: reba.anindyajati@gmail.com

2 Dosen Magister Pembangunan Wilayahdan Kota, Undip Semarang, Jawa Tengah
} 


\section{INTRODUCTION}

As a developing country, Indonesia has a high level of migration as the indicator of the urbanization process. Firman and Rakodi (2009) argue the urbanization that resulting migration in Indonesia occurred due to the dynamic of economic condition. The crisis stimulates people move from rural to the urban area; changes rural economic and reducing remittances. After the great economic crisis hit Indonesia in the late ' 905 , the rural migrants tend to increase in intensity and number; the rural people need to find the alternate source of income to support their livelihood.

Based on this fact, the migration mostly happens in the urban where the economic reason seems to be the basic consideration for the people to be there. The migrant will try to find the best location based on the socio-economic fit with the characters. It might align to their background, land use, density, economic activity and even images of the places. Brown (1991) argues that the place characteristic play an important role in determining migration motivation and the survival in the new places. Therefore, the social movement ended up settled in a particular location will bring unique characters and contribution on that location due to the inhabitant's activities.

Mataram is the capital of West Nusa Tenggara (WNT) Province, has the most complex economic activities, high population, and heterogeneous inhabitants in the province. Regarding Center Bureau of Statistic (CBS) of Mataram, in 2007 Mataram had 356.141 inhabitants and increased up to 413.210 in 2012. Migration also occurs as the consequences of the urban status; recent five years migration in Mataram recorded 36.326 new migrants, the highest among districts or $31 \%$ of all recent migration in WNT Province happened in Mataram. There are some areas are locally famous as the migrant's destination i.e.; Ampenan and Sekarbela District. Sekarbela was a part of Ampenan until 2005 became new administrative area located in the southern of Mataram.

The administration split is a big chance to develop new service center that supported by the existences of the ring road stretched from the west coast of Ampenan, South Sekarbela until East Sandubaya. Based on CBS (2011), Sekarbela is on boost period after declared as new administrative area. It could be seen from 60\% population growth from 36.221 inhabitants in 2000 up to 53.112 in 2010 while Ampenan from 64.650 in 2000 to 78.779 in 2010. CBS also estimates the new migrant composition in Sekarbela during the boom period up to $35 \%$. It shows those two area has become two migrant-center areas that have its own purposes but still have interdependence each other.

Regarding the large number of migrant concentration in Ampenan and Sekarbela, their existence surely has some influence on the surrounding activities such as economic sector or social lives. It needs to find the migrant concentration that represents the way they survive and the dynamic life in the urban area. It proposed to identify whether any correlation between the huge number of migrant and its influence socio- economically in those places. The previous research about the migrant livelihood is a common thing that is already done by some scholars such as Brown (1971), Orford (2003), Fang (2005) and Plantinga (2013). In Indonesia, this research is expected to give more information, especially reveals the influences on the migrant area in Ampenan and Sekarbela that has historical correlation since the previous time. 


\section{METHODOLOGY}

This research is a quantitative paradigm with both quantitative and qualitative in the process. It uses descriptive quantitative approach supported by field verification to understand the qualitative information that is not completely captured in the quantitative method. The quantitative approach tends to value-oriented, uses formula and generalization. In line with Arikunto (2006:12), argues a research categorized as a quantitative tends to be a deductive model, has rigid research design, sampling unit, generalization purpose, and non-direct researcher role. Cresweel (2008) said the survey design is a kind of research which is dealing with quantitative formulation, numbers, and trend of the population by observing some samples, and generate some conclusion to represent the population.

The object in this research is the pre-defined lower and upper middle migrant community by following unknown total population method. In the end, this research will try to eradicate the influences of migrant settlement in Ampenan and Sekarbela from physical and socio-economic aspect.

\section{OVERVIEW OF MATARAM MUNICIPALITY}

\section{Demography of Mataram}

As the capital of West Nusa Tenggara province, Mataram has a high population over the year. In 1980, it was recorded 199.365 inhabitants and increased up to more than 400.000 in 2012.

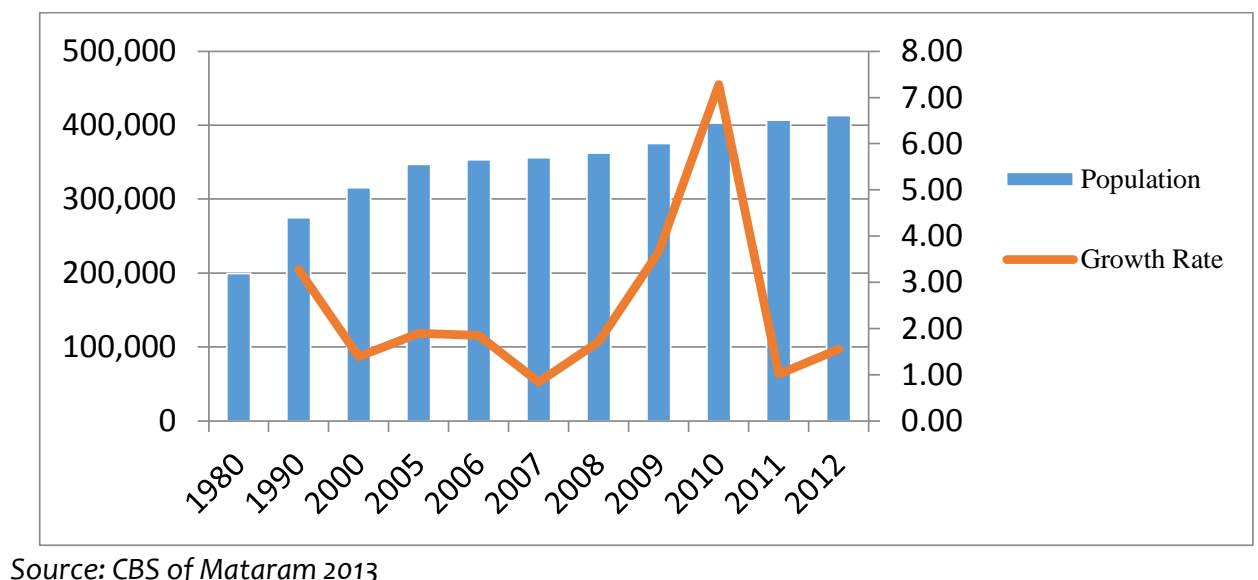

Source: CBS of Mataram 2013

FIGURE 1

POPULATION AND GROWTH RATE OF MATARAM 1980-2012

The population number of Mataram in 2012 based on Figure 1 recorded 413,210 inhabitants in 2012. There is a slight slow of population growth from 2005 to 2008 , which is 346.000 to 362.000 inhabitants. The growth rate trend in Mataram tends to be fluctuated; there was a decrease number from $3.27 \%$ in 1990 to $0.8 \%$ in 2007 and rapidly increased to the peak of $7.28 \%$ in 2010, and decreased up to $1.55 \%$ in 2012.

\section{Ampenan and Sekarbela as migrant concentration area}

New administrative declaration in 2005 resulted in some changes to the demography. Based on CBS data 2012 about ten years population growth indicated that Sekarbela as the new expansion of Ampenan was on the booming period. The almost doubled population number 
from 36.221 in up to 53.112 in 2010 . Ampenan only grew from 64.650 to 78.779 inhabitants. The detail information can be seen in the table as follow;

TABLE 1

THE POPULATION OF MATARAM 1990-2010 PER SUB DISTRICT

\begin{tabular}{|l|l|c|c|c|c|c|c|}
\hline \multirow{2}{*}{ No } & \multirow{2}{*}{ Sub District } & \multicolumn{3}{|c|}{ Population } & \multicolumn{3}{c|}{ Growth Rate } \\
\cline { 3 - 7 } & & 1990 & 2000 & 2010 & $1980-1990$ & $1990-2000$ & $2000-2010$ \\
\hline 1 & Ampenan & 68772 & 64650 & 78779 & $4.17 \%$ & $1.88 \%$ & $2.18 \%$ \\
\hline 2 & Sekarbela & 28733 & 36221 & 53112 & & & $4.66 \%$ \\
\hline 3 & Mataram & 44487 & 57116 & 73107 & $3.44 \%$ & $0.64 \%$ & $2.79 \%$ \\
\hline 4 & Selaparang & 53866 & 69737 & 72665 & & & $0.42 \%$ \\
\hline 5 & Cakranegara & 45312 & 59668 & 64087 & $2.17 \%$ & $1.81 \%$ & $0.47 \%$ \\
\hline 6 & Sandubaya & 32588 & 44484 & 61093 & & & $3.73 \%$ \\
\hline
\end{tabular}

Source: CBS of Mataram 2012

From the table, it is known that since 1980-1990, Ampenan has become the area with the highest growth rate by $4.17 \%$ among all sub districts in Mataram. After the administration split, Sekarbela has become the highest growth by $4.66 \%$ during $2000-2010$. The condition in Sekarbela and Ampenan are also influenced by the existence of migrant in both areas. Linked to the policy about Sekarbela, it is mentioned that Sekarbela after declaration will be functioned as new service center and settlement in southern part of Mataram. It indicates that new settlement will attract new migrant to live in Sekarbela and create new livelihood.

\section{LITERATURE ON MIGRATION AND MIGRANT CONCENTRATION IN THE URBAN AREA}

\section{The basic theory of migration}

Lee's theory on migration (1966) states the migration could be understood as the changing process of residential location, whether permanent or semi-permanent changes. Migration related to the decision making in moving across location due to some condition and consideration. There are 4 elements that influence people act on migration, i.e. origin factors, destination factors, intervening obstacles, and personal decision. In spatial perspectives, Brown (1971) has stated the term of urban migrant lifeline refers to the sequence of residential movements made by household within a single urban area. In general, urban households' movement as the response of the urban environment changes; economic, social and even the environment.

\section{Migrant influence to local activities}

Brown (1991) argues that the place characteristic plays an important role in determining migrant motivation and the survival in the new places. Migrants will only survive when the area is match fit with the needs and can give them an opportunity to develop and create a new livelihood. This condition further will derivate some changes in the environment and land use pattern due to population pressures. The most visible changes may affect the land use by the increase in property demand. Land use changes are affected by multi-interest as Kaiser (1995) argues. There are four main stakeholders who give tension to the land use; market, government, interest (community and locals) and land planners.

Another impact of migration can be seen from the concentration of the migrant member in a particular area. The concentration of migrant could be as an impact of social network and social bond among them. In the process of new settlement development, new migrant tend to 474 
have a tighter bond with the same origin migrant rather than to the natives while previous generations of migrants have better adaptation and assimilation to the native. Flexibility in adaptation is the key to surviving and open more access to economic resources in the urban area. Liu (2012) argues that the social network and adaptation play an important role in the survival strategy to the migrant in a new area. As the consequences of social belonging, communication, and another social network may stimulate migrant to live closely each other. Origin-based and language as the media to strengthen the community gives a unique image to the place. This condition will further develop a specific migrant area.

\section{THE INFLUENCES OF MIGRANT SETTLEMENT IN THE URBAN AREA}

\section{Images of the place and the orientation of migrant movement}

Fracaviglia (1996:65) argues that the settlement and other activities within the city were framed by unique pattern such as road and any initial land use planning in the previous time. The existences of old city Ampenan plays an important role in determining spatial development. It focused in the Simpang Lima, Kebon Roek Market and followed settlement surrounding it such as Kampong Melayu, Kampong Banjar, Kampong Arab, Kampong Cina, Pejeruk, and Dayen Peken. As the shapes of Mataram morphology, the city stretched along the main road from Ampenan to the east.

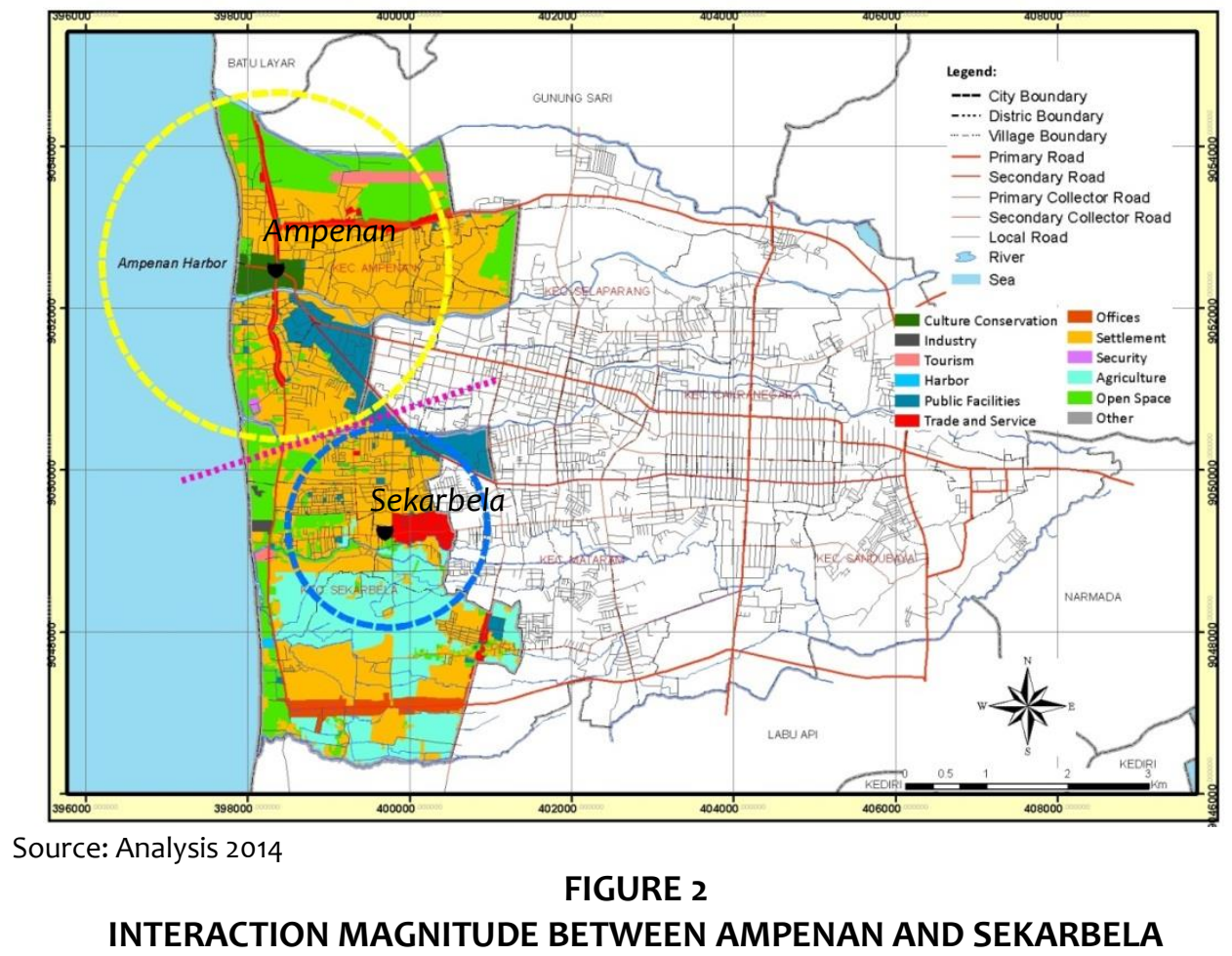

After the administration split, Sekrabela is likely still relying on the services of Ampenan. As a mature area, Ampenan is developed with fully service facilities to its peri-urban. When the administration split occurred, those facilities situated close to the border, regardless the previous economic activity connection, it surely attract the people of Sekarbela to have such activities in Ampenan. The Figure 2 illustrates the distance from each city center to the border. The map shows the blue color as public facilities is stretched from the city center of Ampenan 
to the south. Crossing the border to Sekarbela, it was developed a long time ago and has become one of the important facilities to attract the outsider.

There is a fact of the correlation between social class and movement preferences. The uppermiddle migrant community tends to live outside the city center rather than the lower-middle one. This situation reflects the abilities and the activities within the places. The city centers with various activities offer more chances to the lower-middle migrant community without any specific requirement. The upper-middle community lived in other way behavior. They resided away from the city, worked in the distance by private vehicles.

TABLE 2

THE TENDENCY OF MOVEMENT AMONG THE MIGRANT COMMUNITIES

\begin{tabular}{|c|c|c|c|}
\hline \multirow{2}{*}{ Social class } & \multicolumn{2}{|c|}{ Location } & \multirow{2}{*}{ Remarks } \\
\cline { 2 - 4 } & Ampenan & Sekarbela & Close to the city \\
\hline Lower middle & $74 \%$ & $63 \%$ & Away from the city \\
\hline Upper middle & $69 \%$ & $55 \%$ & Aw
\end{tabular}

Source: Analysis 2014

From the Table 2, it is known $74 \%$ lower middle migrant community of Ampenan moved close to the city center, and $63 \%$ in Sekarbela. The upper middle migrant community of Ampenan $69 \%$ tends to move away from the city center, and $55 \%$ in Sekarbela. This condition shows the movement preferences of the migrant community are aligned with the image of the places. In turns, those considerations will affect the living preferences manifested in the way they concentrated toward the urban area. Furthermore, Ampenan as older area structured with more complexes and a crowd pattern, where the lower middle migrant tend to live close to the city. Otherwise, the upper middle tends to live far from the city center. In Sekarbela, the contra condition happens where both lower middle and upper middle live in the same distance to the city/ service center ( $65 \%$ and $55 \%$ ). This situation could be understood as the phenomena of new city development, where Sekarbela as the expansion of Ampenan and the settlement stretched with equal distance to the peri-urban.

Economically, the inhabitants of Ampenan work on some market-associated activities, while Sekarbela is more formal with white-collar inhabitants. Some of the inhabitants especially in Ampenan have the occupation in trade and services sector close to Kebon Roek. The existence of lower middle migrant in this area has created a new activity beyond the market. Before, the activities were dominated by "the market" itself. But after the migrant came, the activities expanded seen from the location, variation, and even duration. This fact might have a correlation with the image of the places, and otherwise it also interactivity between inhabitants and environment activity. The trader will live close to the market, as the nature of working in efficient way.

\section{The influences of migrant activities in Ampenan and Sekarbela The old town of Ampenan}

- Lower middle migrant community and the informal activities

The lower middle migrant community of Ampenan is often associated with labor. Most of them work in the field that requires manpower rather than skills. As the nature of survival instinct, up to $90 \%$ of the lower middle migrant has alternative income by the secondary job. The secondary job is usually done by the women; there are such as awareness among the women to support family income. This situation is contrary to classical perspectives on 
woman's role in a family. Hoschchild and Machung (1989) argue that classical perspectives see the woman as the internal worker and less reorganization to their work outside the home, and the shift of duo role in women migrant started for economic reasons.

Field verification has been conducted to the local in regard to the high movement frequency of the migrants. It is known that the local perception toward the migrant is positive; it means that the local people see this circumstance as an economic chance. They see the migrant who coming to the area for the low educated people, with many limitations on skills and knowledge. Therefore, it will end up to the contribution in the informal sectors.

In turns, the existence of lower middle migrant in the city center has given a big push to the native's movement to the peri-urban. The more migrant exist in the city; the more density created and adds more complexity to the city. In the other perspectives, it gives a chance to a new business on house rent. Some natives of Ampenan rented their house or even sold them to the migrant and purchase a new house in the suburb. The impact is the increase of IN/ OUT ratio of migration in Ampenan as shown in the Figure 3. Detailed to the IN/ OUT ratios, it shows that the out ratio tend to increase, 0.54 in 2009, increased to 0.67 in 2010, dropped to 0.32 in 2011 and reached the peak 0.91 in 2012.

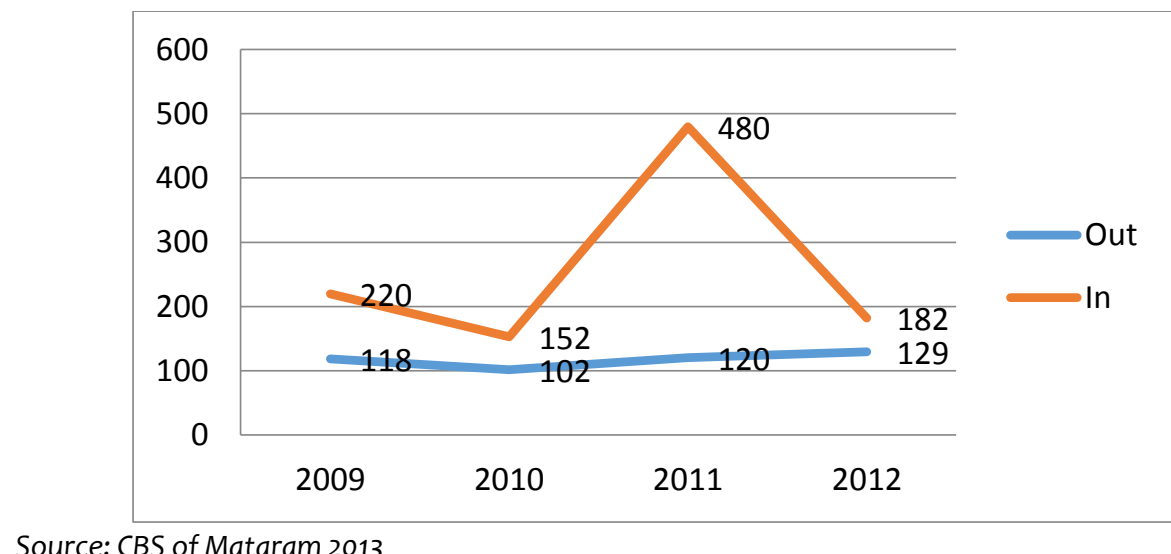

Source: CBS of Mataram 2013

FIGURE 3

IN AND OUT MIGRATION IN AMPENAN 2009- 2012

Regarding the new housing provision in Ampenan, the fact shows the Ampenan is started to seize the land saturation. Based on land use changes 2006-2012 (for settlement only), there was an increase of $6.58 \%$, or $26.9 \mathrm{Ha}$ out of $409.4 \mathrm{Ha}$ as shown in following the Figure 4 . The figure shows the land use changes for settlement tend to decrease over 2009. In 2012, the land use changes for settlement were only $7 \mathrm{Ha}$, lower than previous time reached more than $10 \mathrm{Ha}$. Therefore, house prices in Ampenan relatively more expensive rather than house prices in Sekarbela. A previous research by Khatimah (2003) on land use changes for housing and commerce area associated with its service level, it shows that land use changes in Ampenan was categorized as low among the other sub-district in Mataram. 


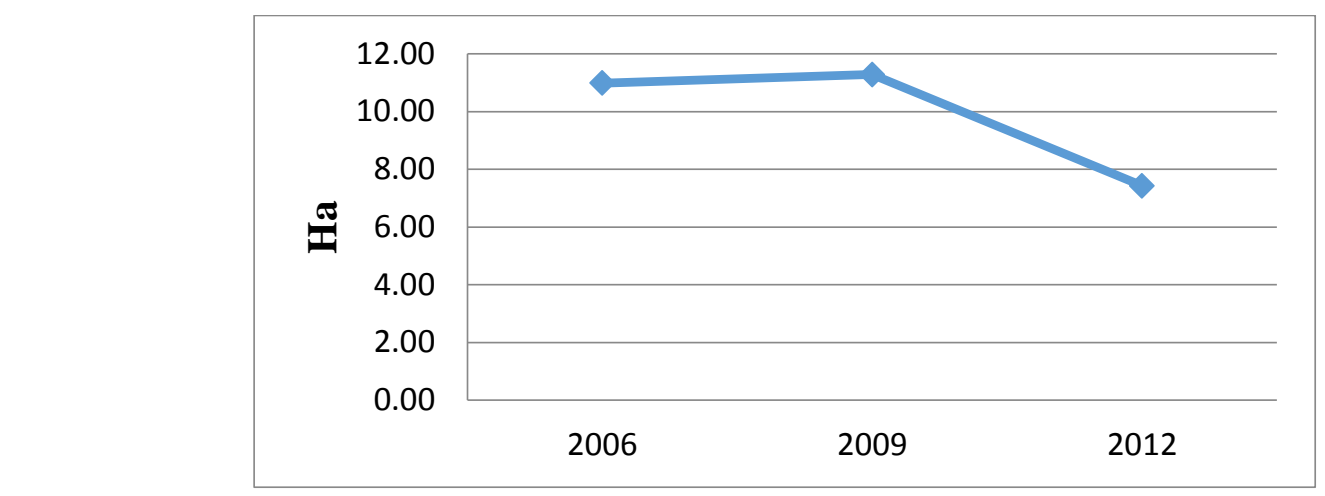

Source: Bappeda Mataram, Land Use Map of Mataram 2006-2010, NOAA Images 2009-2014, and Khatimah 2013

FIGURE 4

LAND USE CHANGES FOR SETTLEMENT IN AMPENAN 2006-2012

- Standalone livelihood of the upper middle migrant community

In the other side, the upper middle migrant in Ampenan is in the contraposition. They had more formal lifestyles and resided in a residential estate, clustered in the eastern and southern part of Ampenan, with a certain distance with the traditional society. This phenomenon can be understood by the stratification theory by Gottdiener (2011); he argues stratification happens when there are clear different on economic ability between the communities. The rich group lives in distances from the lower one, which the communal identities are usually manifested by the economic ability and material indicators. The presence of the upper middle migrant community in Ampenan is quite having an impact on the local community, particularly the lower middle group. From spatial activity perspectives, Ampenan is a center of trade and services that have evolved from the past. The existence of the upper middle migrant community has induced an increased need for housing and commerce facilities that are provided through land conversion.

The results of field investigations indicate a trend of new housing provision in the north and south of Ampenan who still have non-built area. In such cases, the local communities who were experiencing livelihoods changes tend to turn into traders. It is as a logical consequence where their place has a potential of trade and services center.

TABLE 3.

HOUSEHOLD BY OCCUPATION IN AMPENAN 2009-2013

\begin{tabular}{|l|c|c|c|c|c|}
\hline \multirow{2}{*}{\multicolumn{1}{c|}{ Occupation }} & \multicolumn{5}{c|}{ Year } \\
\cline { 2 - 6 } & 2009 & 2010 & 2011 & 2012 & 2013 \\
\hline Agriculture & 240 & 232 & 195 & 208 & 201 \\
\hline Home Industry & 754 & 745 & 745 & 785 & 815 \\
\hline Construction & 1672 & 1679 & 1695 & 1872 & 1872 \\
\hline Trade & 3115 & 3115 & 3101 & 3132 & 3185 \\
\hline Service & 5972 & 5972 & 5978 & 5983 & 5995 \\
\hline Other & 3957 & 3957 & 3957 & 3252 & 3917 \\
\hline
\end{tabular}

Source: Village Profile 2009-2013 \& CBS of Mataram 2009-2013 
The Table 3 about livelihood changes shows that the primary livelihoods (agriculture) tend to decrease from 240 households in 2009 to 201 in 2013. On the other hand, a household with the main activities of trade has increased significantly by 3115 in 2009 to 3185 in 2013.

\section{The new town of Sekarbela}

\section{The lower middle migrant community as the commuters and the petty developers}

Sekarbela is a new developing area in the southern part of Mataram, almost all of the residential estates can be found along the ring road corridor. Therefore, the contribution of the lower middle migrant is less compared to Ampenan. It is caused by the domination of upper middle group over the lower one. As new development area, it is more focused for the upper middle group.

The fact is some of the lower middle group migrants of Sekarbela are those people who previously lived in Ampenan. The differences between the lower middle of Sekarbela to Ampenan are less migration frequency, higher earnings, and longer working distance (commuters). It means the area of Sekarbela still has the high dependency to another area in this case is Ampenan. There are $41 \%$ of the lower middle migrant community worked outside the area. As previously shown in the Figure 2 about the magnitude of Ampenan and Sekarbela shows the northern part of Sekarbela is closely adjacent to Ampenan i.e. Jl Malomba. That corridor is one of the main corridors in Ampenan with the regional level service center, government offices, as well as public facilities.

The existence of the migrant community in Sekarbela gave a change to the local community. The influence is the gradual land conversion that encourages gradual livelihood changes. In Sekarbela, found the tendency of local communities in collaboration with petty developers to provide small-scale housing. It consists of a small (3-5 people) adjoining land owners with up to 1-2 ha area. The housing is proposed for lower middle income, include the migrant. As a case found at JI H Naim, Jempong Baru- Sekarbela, there are some small scale housing by the petty developer.

From the Tax Object Sales Value (TOSV) data by National Land Affairs Agency of Mataram 2012, the price of land on the banks of the ring road is IDR $1,125,000.00 / \mathrm{m}^{2}$. The land price for the areas far from the main road is relatively low. But, in fact, the land price in Sekarbela today achieved 4-5 times higher than the TOSV prices. As the nature of the petty developers who buy the land at a low price, they will seek a location quite far from the road. An example is an agricultural land located in Jempong Baru, especially Dusun Jempong and Geguntur. There found the development of in-between housing and small scale residential estate adjacent to the kampong residents.

In the long term, this condition led to soaring land prices and lifestyle transformation of rural communities. Rising land prices will increase the interest of farmers to sell their land, giving small-scale residential development opportunities that result in the emerging of the "development from the edge".

\section{The upper middle migrant community and local economic transformation}

Both by nature or policy, Sekarbela is a prospectus for upper middle migrant because they can easily find many housing. This condition stimulates domino effect on land conversion. It is shown in Perumnas, it was one exclusive residence in Panji Tilar Street, but just a matter of time, the speculator and developer developed new formal housing along the corridor. The data from Bureau of Regional Development Planning of Mataram as well as a previous 
research by Khatimah (2013) show the land use changes for settlement in Sekarbela tend to increase over the years. During 2006 - 2009 period, there was an increase of $11.34 \%$ new built up area amounted to $32 \mathrm{Ha}$. Previously, the settlement area in Sekarbela was $262 \mathrm{Ha}$ and had became $294 \mathrm{Ha}$ in 2012. The illustration is shown in the Figure 5. The acceleration of land conversion for new housing area was started in 2009. During 2006 to 2009, the growth of new housing was only $7.5 \mathrm{Ha}$. The acceleration in 2009 was the consequence of the local policy on the declaration of Sekarbela as a new administration area.

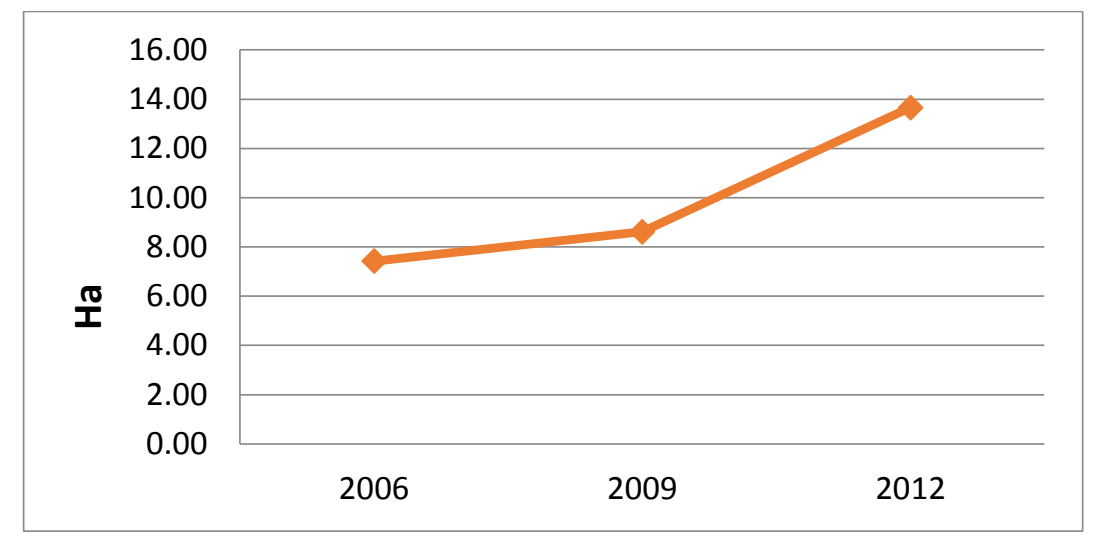

Source: Bappeda Mataram, Land Use Map of Mataram 2006-2010, NOAA Images 2009-2014, and Khatimah 2013

FIGURE 5

LAND USE CHANGES FOR SETTLEMENT IN SEKARBELA 2006-2012

The upper middle migrant in Sekarbela mostly high-income people, $>50 \%$ migrant earn more than IDR 4,000,000 per month. This condition normally placed them exclusively cluster and gated residence. In Sekarbela, as like the nature of the modern society by Baltzell (1958), they have low migration frequency and small family members. From the data, it is known that the upper middle group in Sekarbela made movement $2 x$ or even less, and normal 4-5 family members.

From the field work, it is known that most of the upper-middle migrant in Sekarbela is the formal employer (government officer) and the other are private and businessman. There are interesting facts found during the investigation of some activities done by the upper-middle migrant in correlation with affecting or changing the livelihood/ behavior of local people;

\section{a. The boost of home based industry}

In the recent years, the transformation of land use changes in Sekarbela is not only by the housing project, but also the industry (warehouse) and commercial facilities. For that reason, the emerging growth of new commercial activities has influenced the local behavior. Some migrant who resided in the new residential estate also has side job such as distributing the local product to the outside area. They purchase the product from the Mataram Craft Center and redistribute the product to large cities in Java such as Surabaya, Bandung, and Jakarta. This place as a promotion hub for the SMEs that managed by the Cooperation and Trade Agency of Mataram

b. Property as the mode of investment

In other perspectives, land occupation by the migrant might also play an important role in emerging the tendency of land conversion. As also mentioned by UN-Habitat (2012) and Surya (2006) the common trend in the developing world and Indonesia today is about land investment for housing and property. 
TABLE 4

\section{MIGRANT ASSETS OWNERSHIP BASED ON THE OCCUPATION IN AMPENAN AND SEKARBELA}

\begin{tabular}{|c|c|c|c|}
\hline No & Location & Occupation & Percentage \\
\hline \multirow[t]{4}{*}{1} & \multirow[t]{4}{*}{ Ampenan } & Civil servants & $50 \%$ \\
\hline & & Trader & $35 \%$ \\
\hline & & Employees & $12 \%$ \\
\hline & & Other & $3 \%$ \\
\hline \multirow[t]{4}{*}{2} & \multirow[t]{4}{*}{ Sekarbela } & Formal Employees (private enterprise) & $50 \%$ \\
\hline & & Civil servants & $30 \%$ \\
\hline & & Trader & $15 \%$ \\
\hline & & Other & $5 \%$ \\
\hline
\end{tabular}

Source: Analysis 2014

From the Table 4, the economic ability becomes the main reason for the migrant's assets ownership. The table informs that in Ampenan, 50\% of migrant who has assets are civil servants, and $50 \%$ migrant in Sekarbela are formal employees. The assets discussed here mostly are in the form of land-plot, and the rest are house and shops. It shows that the migrant who works in a formal activity (civil servant, employees for a private enterprises, etc.) has some assets rather than the informal.

The connection between local communities towards upper middle migrant is seen from the derivate impact of new development in Sekarbela. These conditions manifested by land use changes that result in the livelihoods changes of the local communities. The people who experienced livelihood changes are the people who work in the agriculture sector, as shown by the following table

TABLE 5

HOUSEHOLD BY OCCUPATION IN AMPENAN 2009-2013

\begin{tabular}{|l|c|c|c|c|c|}
\hline \multirow{2}{*}{ Occupation } & \multicolumn{5}{|c|}{ Year } \\
\cline { 2 - 6 } & 2009 & 2010 & 2011 & 2012 & 2013 \\
\hline Agriculture & 1556 & 1556 & 1560 & 1561 & 1473 \\
\hline Home Industry & 866 & 908 & 908 & 889 & 1207 \\
\hline Construction & 613 & 613 & 735 & 613 & 748 \\
\hline Trade & 1184 & 1184 & 1251 & 1184 & 1342 \\
\hline Service & 257 & 257 & 284 & 257 & 296 \\
\hline
\end{tabular}

Source: Village Profile 2009-2013 \& CBS of Mataram 2009-2013

The communities who have subsistence in farming must change into non-agricultural livelihoods. This situation has a large simultaneous impact because it affects the two groups, namely the landowner and the worker/ laborer. The local community groups that previously to be a land owner has turned into the trader or offering any services. When their land is sold, the money earned is used for other purposes such as buying a motorcycle to motorcycle-taxi, open a shop, or buy another property. In the labor family, the transformation of agricultural land causing unemployment. It is because of the associated farm workers as jobs that do not require much capital or expertise. 


\section{CONCLUSION}

There are some points noted in this research about migrant settlement impact to the socioeconomic environment i.e. the different characters that come out from the economic factors. It influences people to live based on the economic condition, and the different settlement triggers different atmosphere in the dynamic of daily activities. In turn, they will have different influence to the surrounding environment.

The migrant characters in Ampenan and Sekarbela are different. It is not only comes from the individual migrant itself, but also the environment. It is known that the economic condition stratifies migrant into the different level and push them to behave differently. Economic aspects are the most visible way to distinguish them and create unique appearances to the way they behave. The lower middle migrant community with their informal activities take a work in urban spaces creates supporting activity beyond the main one. Upper middle migrant communities with their exclusiveness lived far from the city and fashioned with formal economic style. Beyond the economic variables, the social variables such as family member (that further associated with the colleagues and the clustering behavior) and the migration number contribute significantly in determining the way of behavior.

Although there is the same the tendency of movement among the migrant communities (living distance to the city) between the migrant in Ampenan and Sekarbela, but there is a different dynamic activity seen from socio-economic perspectives. It is seen from the activity that exists in the migrant community; the activities are not only representing their economic level and what they need, but also contributes to the image of the places due to the behavior. It is important to note that the lower middle migrant community or upper middle migrant community in both places behave differently due to different opportunity related with the economic activity around them. Therefore the factors such as economic activity have a strong influence in determining the influences between the migrant groups to the local community.

\section{REFERENCES}

Arikunto, Suharsimi. 2006. Prosedur Penelitian, suatu pendekatan praktik. Jakarta: Rineka Cipta Baltzell, E Digby. 1958. Philadelphia Gentlemen; the Making of a National Upper Class. New Jersey: Transaction publisher.

Brown, Lawrence A. 1971. Intra Urban Migrant Lifelines; spatial view. Journal of demography, volume 8 no 1.

Brown, Lawrence A. 1991. Place, Migartion and Development in the Third World - An Alternative View. London: Routhledge.

Creswell, W. John. 2008. Research Design; Qualitative, Quantitative, and Mixed Method. Los Angeles: Sage

Fang, Yiping. 2005. Residential Satisfaction, Moving Intention and Moving Behaviors: A Study of Redeveloped Neighborhoods in Inner-City Beijing. Routhledge Housing Studies, Vol. 21, No. 5, 671-694, September 2006

Francaviglia, Richard V.1996. Main Street Revisited. lowa : lowa University Press

Gotdiener, Mark and Ray Hutchinson. 2011. The New Urban Sociology, 4th Edition. Colorado: Westview Press 
Hochschild, Arlie and Anne Machung. 1989The Second Shift: Working Parents and the Revolution at Home. New York: Viking Penguin

Kaiser, Edward J et al.1995. Urban Land Use Planning. Chicago : University of illionis Press Reinhold Company, Inc

Khatimah, Khusnul. 2013. Kajian Efektivitas Pelayanan Ruko di Kota Mataram. Thesis. Universitas Diponegoro Semarang

Lee, Everett S. 1966. A Theory of Migration. Demography, Vol. 3, No. 1. (1966), pp. 47-57.

Liu, Ye et al. 2012. The social networks of new-generation migrants in China's urbanized villages: $A$ case study of Guangzhou. Habitat International 36 (2012) 192-200

Orford, Scott. 2004. Identifying and comparing changes in the spatial concentrations of urban poverty and affluence: a case study of inner London. Computers, Environment and Urban Systems Volume 28, Issue 6, November 2004, Pages 701-717. AGILE 2003

Plantinga, Andrew J et al. 2013. Housing prices and the inter- urban migration. Regional Science and Urban Economics Volume 43, Issue 2, March 2013, Pages 296-306

Rakodi, Carole and Tommy Firman. 2009. Planning for Extended Metropolitan Region in Asia, Jakarta; Indonesia. Global Report on Human Settlement. Available from http://www.unhabitat.org/grhs/2009

Surya, Aldwin. 2006. Kebijakan dan praktik kepemilikan rumah; studi kasus di Kota Metropolitan Medan. Wahana Hijau, Jurnal Perencanaan dan Pengembangan Wilayah, vol 2 no 1 agustus 2006

UN-HABITAT. 2012. Land Records for the Poor Participatory. Affordable. Credible. Equitable. 